\title{
VII. Observations on the spots of the sun, and the nature of the light of that luminary
}

\section{Von Hahn}

To cite this article: M. Von Hahn (1801) VII. Observations on the spots of the sun, and the nature of the light of that luminary , Philosophical Magazine Series 1, 11:41, 39-44, DOI: $10.1080 / 14786440108675953$

To link to this article: http://dx.doi.org/10.1080/14786440108675953

曲 Published online: 18 May 2009.

Submit your article to this journal \lceil

Џll Article views: 2

Q View related articles $₫$ 
motion, in confequence of having wheels of different diameters, and for covering the rider from the fun, may feem to refemble fome of our prefent carriages more nearly than has been fuppofed, yet do not fo ftrikingly differ from thofe which were common among the antients as to excite much furprife. But the latter appear, indeed, extraordinary: they poffeffed all the advantages, as it fhould feem, of the cbariot waywifer, which has been believed to have been firft invented by fome members of our Royal Society about the year 1662; and of the pedometer, which is at prefent manufactured, I hink, under a patent.

London, I am, Sir,

Your obedient fervant,

October $8,180 \mathrm{r}$.

R. HERON.

VII. Obfervations on the Spots of the Sun, and the Nature of the Light of that Luminary. By M. VON HAHN *.

UR experience of the various effects produced by the fun's rays, and particularly the doctrine of latent heat and fpecific heat, feem to confirm the opinion that light is an actual body which ftreams forth from the fun, and which is connected, in a variety of ways, with the bodies of our earth. The determination of the following queftion, which belongs peculiarly to chemiftry, "Whether the fun be actually a burning body, or only attracts the illuminating matter from the furrounding expanfe of the univerfe?" may receive fome illuftration from continued obfervations made on the body of that luminary.

One great difficulty here is, that the fun has a peculiar light, and we are accuftomed only to confider objects which almoft continually receive their light from without, and which commonly produce thadows more or lefs perceptible according to the different directions and ftrength of the light which falls upon them. Now our eyes, being accuftomed to thadows and projecting images, by beholding an uncommon kind of illumination are thrown into embarraffment, and cannot bring the images in harmony with fenfation, the bafis of all perfpicuity.

One may obferve the fun a long time without difcovering any other fpots than thofe which are common. The firlt view, therefore, of the fo called folar faculre produces an

in From Profefor Bode's Afronomical Aimanai for the 2 icar 1796.

$$
\mathrm{C}_{4} \text { agreeable }
$$


agreeable furprife, as it exhibits fomething very different from what we fee in thofe parts of furrounding nature which are neareft to us. With a Herfchel's telefcope of feven feet, one beholds with aftonifhment, and very diftinetly, in thofe fpots in the middle of the fun's orb, parts befet with little bills feparated by valleys, and fingle mountains, of a proportional height, which project ftrong thadows. It is worthy of remark, ihat thefe objects have as diminithed an appearance as when one looks at things from a great height. The caufe of this is to be fought for in the fituation of the light which falls on them, and belongs to thofe optical deceptions that muft occur fo frequently in obferving the fun, and on a knowledge of them depends the whole fecret of forming a proper judgment refpecting the folar bodies.

The finenefs of the delineation, the fcenic appearance, and the regularity of thefe objects, induce one to believe that folar landficapes are here actually reprefented; and totally deftroy the idea of the fun being a flaming body; for it is impoffible that the irregular movement of flame could ever produce fuch fcenes. Thefe parts are, at times, of a more whitith colour; but it ought to be particularly remarked that they have a fomewhat dimmer light than the reft of the fun's orbit, which is every where luminous. If the divifion of the lights and thadows, the kind of illumination, and the gradation of the thades, be accurately obferved and examined, we thall be obliged to admit that thefe faculæ in the fun are landfcapes.

The moft important obfervation here is, that when there are a group of fuch landfcapes the fhadows are almoft always projected to one fide, and are fharp-pointed. This circumftance ferves to render clear to the eye a confufed mixture of fpots.

Let one fearch out, in the neighbourhood of fuch groups, fmall, fingle, infulated fpots, and obferve whether there is feen near them a weak gradation of thade, or a luminous vapour which is very familiar to us, and which thows that the light illuminates an eminence on all fides, but not with equal ftrength. If the eye is once accuftomed to the effect that hence arifes, it can with great eafe convert an often exceedingly compound mixture of dark parts and luminous fpots into well arranged images.

There are certainly cafes in obferving the fun when draftfmen and painters only could be able to arrange properly the mixture of faint fpots, and to obviate the deception which arifes from half thadows. When an eminence, for example, is fo ftrongly enlightened by the luminous matter near it, 
that one fide of it has the fame brightnefs as the folar light itfelf, we then no longer fee an eminence, but only a faint fpot produced by the half thadow on the other fide. But if the direction of the ftrongeft half thadows towards any part of the fun's difk be once known, we may then venture to examine the greateft collection of luminous faculæ, and diftinguifh them with the beft fuccels. They then lofe their ftrange appearance; and the eye becomes convinced that an affemblage of eminences and plains could exhibit fuch an appearance only by a light proceeding from different fides, though with various degrees of ftrength. Befides, it may fometimes be the cafe that the light may be higher, nearer, or at a greater diftance in one diftrict than another; and therefore it is difficult, under all thefe circumftances, to form a right judgment of an object in the fun.

The fun, therefore, mult be inclofed in a luminous covering, or furrounded by an atmofphere of light-an idea firtt ftarted by Mr. Bode; but the peculiar quality of it remains to be more fully inveftigated. A globular covering of boiling light feems to be too moveable to produce the above phænomena. The irregular fpreading of the furrounding flame would every moment change the fcene; as a mixture of luminous matter with the folar atmofphere would give it an obfcure appearance, and be contrary to the fmoothnefs of that line by which the folar difk is bounded.

The fun may be confidered as an opake body of itfelf, and furrounded by an atmofphere almoft fimilar to ours; but the luminous matter as an uncommonly fine fluid, which, like liquid naphtha, floats on this atmofphere, and, on account of its great lightuefs, can never fink down under any circumftances whatever.

The atmofphere of the fun, by his rotation, being raifed higher under the equator, will be depreffed towards the polar regions. The luminous matter is attracted from the celeftial expanfe; and this hypothefis, which has been adopted by many, appears to be the true one, becaufe the phrnomena on the furface of the fun can be beft cxplained by it. It muft however be premifed, that no more luminous matter is attracted than may be neceffary to form almoft a total covering to the fun; and that, on account of the continual influx towards the poles, it muft often happen that the quantity there will be diminifhed. This is a confequence of the thing itfelf; for, if it be admitted that the feparation of the luminous matter is performed by a chemical affinity, the effect of which is facilitated by the fun's rotation, the attraction will ceafe when the folar atmofphere has imbibed a fufficient quantity. 
quantity. By obferving the fun, we perceive not only the luminous matter, but the light reflected, in a lively manner, from the fun's body; and at fuch a diftance they cannot be diftinguifhed from each other. Through a deception of our fenfes, we often take the effect for the caufe, and feek for the object in the light, and then again for the light in the object.

But as the atmofphere, greatly expanded at the equator, muft fink down fomewhere from well known caufes, the luminous matter flies off on all fides towards the lower parts, and illuminates the parts it left, no longer from above, but laterally. Here we difcover the folar faculæ; and if in thore parts there be inequalities, there arife then half thadows, which are almolt loft in the tint of the ground. If the obferver fails in his judgment of the angle of inflection, he fees only a mixture of faint fpots, and no landfcapes.

It will now be eafier to explain the proper fpots in the fun, as they are called. They are parts of the fun lying under full thadows, which muift naturally arife when the illuminating fluid draws itfelf fo far back from the horizon of that neighbourhood, that no more ravs can reach its centre. The contraft with the reft of the dazzling difk of the fun increafes their blacknefs, and gives them the appearance of a burut coal, or cinder. We hall be readily convinced that fome parts of the fun's furface may lie in a full thadow, when we reflect on the great fize of thefe fpots, and confider the height of the luminous fluid to be fmall, or equal to about the diftance of our higheft clouds from the earth. It cannot be higher, elfe no perceptible half fhadows would be occafioned, becaufe the thadows of bodies become fmaller in proportion to the height of the illuminating point. The irregularity of the fpots arifes partly from the different fituations of the luminous matter, and partly alfo from the inequality of the bottom. That remarkable vapour by which they are furrounded is occationed by a kind of crepufeulum, by which the fide light is conveved to the moft diftant part from the centre of the fhadow. As the luninous matter now appears to be more fparingly divided in the folar atmofphere, a place may be totally deprived of light by its retiring: but near the boundary of the light it is directed tawards the bottom, though fomewhat weakened by the refraction and reflection of the rays, as is the cale in our morning and evening crepufcula; and the fpots by thefe meaus obtain their conical form. If we confider this vapour more attentively, the before-mentioned landicapes can be clearly diftinguifhed according to the above method; and if the full hodows have confiderable 
confiderable inequalities, there arife forms of all kinds which exhibit no determined figure, until we become no more acquainted with the fituation of the thadows. On the fummits of fuch eminences may be clearly feen rows of luminous points, which, however, arife from a reflected light; but, on account of their livelinefs, are taken for the luminous matter itfelf. They feem to be, as it were, feparated portions of the folar atmofphere, which float about within the conical cavities. But on clofer examination this deception vanifhes.

Laftly, hould we fuppofe an atmofphere filled with clouds, enlightened from above by the luminous matter, the great blacknefs of the fpots, and the matter which furrounds them, would oppofe fuch an idea. Such a continual phænomenon is founded on invariable caufes, and cannot be reconciled with the changeable nature of clouds. A real folar landfcape may be recognized to be the fame before feen, even after fome time, when the direction of the light which falls upon it has changed.

It is more than conjecture that the fun feparates the luminous matter from the firmament, and partly appropriates it to itfelf and partly tranfmits it to other bodies, which, on account of their lefs magnitude, are unable to effect the fame. As fo many ftars thine with their own light, it is probable that they all derive it from the fame fource; and that the immenfe fpace of the firmament contains this all-enlivening matter, which nature bas dealt out with a fparing hand, and feems to have deftined for the moft important purpofes.

The phænomenon of the zodiacal light may be very naturally explained according to thefe ideas. The feparation of the light takes place more at the fun; it floats on its atmofphere in exceedingly fmall quantity; and, as it ftreams out immediately in all directions, the terreftrial bodies are $\mathrm{fe}$ cured from immoderate heat by this tendency to diverge. The attraction of the luminous matter from the firmament muft extend to a confiderable diftance; for that fet free at the fun is fupplied by another quantity, which feeks for an equilibrium, and therefore forces itfelf towards the folar equator. It accumulates therefore in thofe parts; and, as it is half feparated, on account of the attraction of the fun acting at that diftance, this mean ftate produces the palenefs of the zodiacal light. This conjecture feems' to be confirmed by a remark of Caffini. At a time when the folar fpots were invifible, no zodiacal light was to be feen. The abfence of the fpots flows a fuperabundance of the luminous matter on the fin ; confequently none is feparated, and thefe phænomena muft ceafe. Were their feat in the folar atmolphere, they 
thow themfelves more ftrongly the more widely the light is difperfed over the body of the fun.

Pofterity, perhaps, will be able to deduce the caufe of the northern lights and other phænomena from thefe fuggeftions refpecting the production of the luminous matter, and to anfwer the important queftion- " By what circulation is that noble matter, which diffufes light and heat throughout all nature, again conveyed back to infinite fpace; or whether deftined and employed for the formation and maintenance of organic bodies?"

\section{Experiments on Platina. By L. PROU ST*}

1. Of the foreign Bodies mixed with native or crude Platina.

$\mathrm{T}$ L HE bodies generally mixed with platina are ftony and metallic fand, pyrites, gold, and mercury. The firft kind of fand confifts of fmall rock cryftals and fragments of a hyacinth colour; the fecond confifts of ferruginous fand of two forts : the one octaedral, and fufceptible of being attracted by the magnet, among which there are fome that do not poffefs that property till after being heated : the other fort is equally black and angular; but the angles are deftroyed in fuch a manner, that it is not poffible to determine their figure, which feems to announce that they are not fo hard as the preceding. The latter are not fufceptible of being attracted by the magnet, even after they are heated, and when analyfed they exhibit new fubftances combined with iron; phænomena by which we are authorized to confider them in their union as a mineralization of a peculiar kind, as will be feen hereafter.

\section{On the Metbod of feparating the Sand from the native or crude Platina.}

Place three or four pounds of crude platina on a large table the edges of which are fomewhat raifed, and at the diftance of a foot from one of the fides; then fpread it out, by means of a card or a rule, in fuch a manner as to occupy the fpace of about two feet, and blow upon it obliquely with a pair of hand bellows, to make the fand, which is always lighter than the gold or platina, pafs to the oppofite fide. If this operation be repeated five or fix times, taking care to

* From Amales de Hiftria Natural, Madrid 1799 , No. I. 